\title{
Biochar-Compost Interactions as Affected by Weathering: Effects on Biological Stability and Plant Growth
}

\author{
Marie-Liesse Aubertin 1,2,*, Cyril Girardin ${ }^{2}$, Sabine Houot ${ }^{2}$, Cécile Nobile ${ }^{3}$, David Houben $\left.{ }^{3}{ }^{(}\right)$, Sarah Bena ${ }^{4}$, \\ Yann Le Brech ${ }^{4}$ and Cornelia Rumpel ${ }^{1, *}$ (D) \\ 1 Institute of Ecology and Environmental Sciences, UMR 7618, CNRS-UPMC-UPEC-INRA-IRD, \\ Sorbonne University, 75005 Paris, France \\ 2 National Institute for Agricultural Research, Ecosys Soil, UMR INRA-AgroParisTech, \\ 78820 Thiverval-Grignon, France; cyril.girardin@inrae.fr (C.G.); sabine.houot@inrae.fr (S.H.) \\ 3 UniLaSalle, AGHYLE, 60026 Beauvais, France; cecile.nobile@cirad.fr (C.N.); \\ david.houben@unilasalle.fr (D.H.) \\ 4 LRGP-CNRS, Lorraine University, 54000 Nancy, France; sarah.bena@univ-lorraine.fr (S.B.); \\ yann.le-brech@univ-lorraine.fr (Y.L.B.) \\ * Correspondence: marie-liesse.aubertin@inrae.fr (M.-L.A.); cornelia.rumpel@inrae.fr (C.R.)
}

Citation: Aubertin, M.-L.; Girardin, C.; Houot, S.; Nobile, C.; Houben, D.; Bena, S.; Brech, Y.L.; Rumpel, C. Biochar-Compost Interactions as Affected by Weathering: Effects on Biological Stability and Plant Growth. Agronomy 2021, 11, 336. https:// doi.org/10.3390/agronomy11020336

Academic Editor: Domenico Ronga

Received: 20 January 2021

Accepted: 9 February 2021

Published: 13 February 2021

Publisher's Note: MDPI stays neutral with regard to jurisdictional claims in published maps and institutional affiliations.

Copyright: (c) 2021 by the authors. Licensee MDPI, Basel, Switzerland. This article is an open access article distributed under the terms and conditions of the Creative Commons Attribution (CC BY) license (https:// creativecommons.org/licenses/by/ $4.0 /)$.

\begin{abstract}
Biochar addition to compost is of growing interest as soil amendment. However, little is known about the evolution of material properties of biochar-compost mixtures and their effect on plants after exposure to physical weathering. This study aimed to investigate the physicochemical characteristics of fresh and weathered biochar-compost mixtures, their biological stability and their effect on ryegrass growth. To this end, we used the contrasting stable isotope signatures of biochar and compost to follow their behavior in biochar-compost mixtures subjected to artificial weathering during 1-year of incubation. We assessed their impact on ryegrass growth during a 4-week greenhouse pot experiment. Weathering treatment resulted in strong leaching of labile compounds. However, biochar-compost interactions led to reduced mass loss and fixed carbon retention during weathering of mixtures. Moreover, weathering increased carbon mineralization of biochar-compost mixtures, probably due to the protection of labile compounds from compost within biochar structure, as well as leaching of labile biochar compounds inhibiting microbial activity. After soil application, weathered mixtures could have positive effects on biomass production. We conclude that biochar-compost interactions on soil microbial activity and plant growth are evolving after physical weathering depending on biochar production conditions.
\end{abstract}

Keywords: biochar; compost; isotopic signature; carbon mineralization; plant growth

\section{Introduction}

According to the last report of the Intergovernmental Panel of Climate Change (IPCC), global temperatures have increased by $1{ }^{\circ} \mathrm{C}$ above pre-industrial levels due to human activity [1]. Further increase should be limited to $1.5^{\circ} \mathrm{C}$ in order to prevent dangerous climate change. To achieve this goal, active carbon dioxide removal from the atmosphere and its storage is needed [1]. Soil carbon sequestration and biochar application to soils may be used for this purpose. As negative emission technologies (NETs), their implementation may be able to achieve long-term carbon sequestration and may have advantages over the other NETs related to their effect on land use, water use and energy requirement [2].

Soil carbon (C) sequestration may be enhanced by the addition of organic amendments. While organic residues such as plant material or manure are usually transformed into amendments through composting, they may also be the feedstock for biochar production [3]. Biochar is a solid pyrolysis product intended to be used as soil amendment [4]. It is mainly composed of aromatic $\mathrm{C}$ and has favourable properties such as large porosity and surface area in addition to high cation exchange capacity, depending on feedstock, pyrolysis 
conditions and particle size [5-7]. Biochar is known to improve soil properties such as water retention under drought conditions [8], and soil aggregate stability and porosity $[9,10]$. Due to its low nutrient content, biochar should be combined with nutrient additions through mineral fertilizers, compost and/or growth promoting micro-organisms to further increase its beneficial effects on plant growth when applied to soil [3]. On the other hand, compost is rapidly mineralized after soil application and its carbon sequestration potential may be enhanced by combination with organic and inorganic additives [11]. Mixtures of both materials may therefore be an innovative practice, leading to more efficient soil amendment as compared to their single use.

Biochar combination with other organic amendments may have synergistic effects on organic $C$ retention, which were attributed to physical protection of compost by its occlusion into aggregates or adsorption on biochar surface [12-14]. Other studies found that biochar and mature compost mixtures induced a negative priming effect [15] or a neutral effect [16] on C mineralization when compared to application of compost. Soil addition of biochar-compost mixtures was shown to promote plant growth, biomass accumulation, yield and to improve soil properties such as water holding capacity [17-22]. Yet the synergistic effects of freshly applied biochar-compost mixtures on plant growth and performance are still under debate [23]. Indeed, application of fresh biochar-compost mixture has been found to have neutral [18] or even antagonisms effects [23]. This may be due to release of toxic compounds contained in the biochars' labile fraction [24-27] or to low availability of nutrients due to the biochars' high sorption capacity [23].

When applied to the field and exposed to weathering, the mixture effects may prevent carbon and nitrogen losses as compared to the single use of compost and biochar [28]. Physical weathering may increase the biological stability of biochars and reduce their priming effect on native SOM mineralization [29]. Moreover, weathering may change the biochar structure [30] and its effects on soil properties [8]. These effects may also change the compost-biochar interactions in mixtures and their amendment effects. Indeed, several studies observed an alleviation of beneficial effects of biochar-compost addition on biomass production over time [31-33]. However, to the best of our knowledge, no studies have focused on the effect of weathering on biochar-compost mixture properties and their biological stability.

Therefore, the aim of the present study was to investigate the effect of artificial weathering on chemical characteristics and biological stability of biochar-compost mixtures and the consequences for plant biomass production after soil amendment. We used two industrially produced biochars from maize and Miscanthus, a green-waste compost and the corresponding biochar-compost mixtures. The mixtures and pure media were subjected to a physical weathering to mimic natural aging mechanisms. Thanks to contrasting stable carbon isotope ratios of biochars derived from C4 plants and compost derived from C3 plants, we were able to monitor the mineralization of the two components of the mixtures during a 1-year of laboratory incubation with a soil inoculum. In addition, we investigated in a 4-weeks pot experiment the effect of fresh and weathered biochar-compost mixtures on ryegrass growth growing on two different soils. We hypothesized that (i) biochar addition to compost would induce synergetic effects on biological stability and plant growth and that (ii) physical weathering would weaken these interactions.

\section{Materials and Methods}

\subsection{Biochar and Compost}

Biochars were produced from maize cobs (Zea mays L.) and elephant grass (Miscanthus $\times$ giganteus, Greef and Deuter), through pyrolysis without oxygen during $10 \mathrm{~min}$ at respectively 450 and $550{ }^{\circ} \mathrm{C}$. Pyrolysis was performed by VTGreen (Allier, France), using an industrial pyrolysis reactor (Biogreen ${ }^{\circledR}$ Pyrolysis Technology, ETIA, Oise, France). The compost was made from green wastes at the platform of Fertivert (Normandy, France). The composting process consisted of 4 months fermentation and 2 months maturation. Three compost turnings were applied. The biochar from maize cobs and the compost are the 
same than the ones used in Nobile et al. [34]. General parameters of the biochars and the compost are listed in Tables 2 and 3. Biochar-compost mixtures were prepared by mixing $20 \%(w / w)$ of each biochar with $80 \%(w / w)$ of the compost. The biochars and mixtures were air-dried at ambient temperature and the compost was stored at $4{ }^{\circ} \mathrm{C}$.

\subsection{Physical Weathering}

The mixtures and pure media were subjected to a physical weathering through wetdrying and freeze-thawing cycles to mimic natural aging mechanisms. The weathering procedure was inspired by Naisse et al. [29]. Briefly, we placed $100 \mathrm{~g}$ (d.w.) of compost or biochar-compost mixtures in PVC cylinders $(\varnothing 9.5 \mathrm{~cm})$. Two PVC cylinder $(\varnothing 5 \mathrm{~cm})$ were used for the weathering of $30 \mathrm{~g}$ of maize and Miscanthus biochars. We covered the bottom of all tubes with a polyamide canvas with $20 \mu \mathrm{m}$ mesh size (SEFAR-Nitex, Sefar AG, Haiden, Switzerland) and placed them on smaller tubes of $10 \mathrm{~cm}$ height to elevate the device. All was then put in a $10 \mathrm{~cm} ø$ beaker, in order to recover the lixiviates (Supplementary Material, Figure S1). We mimicked weathering processes through three successive cycles including three cycles of wetting/drying and three cycles of freezing/thawing. Wetting/drying steps consisted of saturating the samples with distilled water, leaving them at room temperature during $3 \mathrm{~h}$ followed by drying of the sample at $60^{\circ} \mathrm{C}$ overnight. Freezing/thawing steps consisted of saturating samples with distilled water with the same amount as for the previous cycles, freezing at $-20{ }^{\circ} \mathrm{C}$ overnight and thawing during $6-7 \mathrm{~h}$ at $28{ }^{\circ} \mathrm{C}$. We replicated these experiments 2 times. At the end of the weathering procedure, we dried the solid samples at $60{ }^{\circ} \mathrm{C}$ during 2 days and lixiviates until complete evaporation. Mass and carbon loss after artificial weathering were assessed by mass balance.

\subsection{Material Properties: Physico-Chemical, Elemental and Thermogravimetric Analysis}

To measure $\mathrm{pH}$ and electrical conductivity (EC), $2 \mathrm{~g}$ of sample were mixed with $40 \mathrm{~mL}$ of distilled water and centrifugated for $1 \mathrm{~h}$. The $\mathrm{pH}(780 \mathrm{pH}$ meter, Metrohm, Herisau, Switzerland) was measured in the supernatant and the mixtures were filtered (glass microfibres paper, Fisherbrand) before EC (InLab ${ }^{\circledR}$ 738-ISM, Mettler Toledo, Columbus, Ohio, USA) measurement. We evaluated the effect of weathering on dissolved organic carbon content (DOC) and elemental content. For DOC determination, $2 \mathrm{~g}$ of dried samples were sieved at $2 \mathrm{~mm}$ and mixed with $40 \mathrm{~mL}$ of distilled water, $(1: 20 \mathrm{w} / \mathrm{v})$ ratio. The samples were shaken during $1 \mathrm{~h}$, centrifugated at $4750 \mathrm{t} / \mathrm{min}$ during $20 \mathrm{~min}$ and the supernatant recovered by filtration (glass microfibres paper, Fisherbrand). DOC was analysed using a Total organic carbon analyzer (TOC-5050A, Shimadzu, Marne-la-Vallée, France). The determination of $\mathrm{C}, \mathrm{H}, \mathrm{N}$ and $\mathrm{O}$ of solid samples was performed using a CHN-O analyzer (FlashEA 1112 Series, Thermo-Fisher Scientific, Illkirch, France).

Ash content, volatile matter and fixed carbon of dry matter were determined by thermogravimetric analyses (TGA/DSC1 STAR System, Mettler-Toledo, Viroflay, France). The samples (in $70 \mu \mathrm{L}$ crucibles, approx. $6-7 \mathrm{mg}$ ) were first heated at $105{ }^{\circ} \mathrm{C}$ during $30 \mathrm{~min}$ to determine the moisture content. Thereafter, the temperature was increased by $15{ }^{\circ} \mathrm{C}$ min $^{-1}$ to $900{ }^{\circ} \mathrm{C}$ during 40 min under $\mathrm{N}_{2}$ atmosphere to determine volatile content. Temperature was then kept at $900{ }^{\circ} \mathrm{C}$ under air flux $\left(50 \mathrm{~mL} \mathrm{~min}^{-1}\right)$ for $6 \mathrm{~min}$ to determine ash content.

\subsection{Biological Stability: Incubation}

Laboratory incubation was carried out under optimum conditions after the addition of a microbial inoculum ( $4 \mathrm{~mL}$ soil inoculum per $100 \mathrm{~g}$ of sample). The inoculum was prepared with $50 \mathrm{~g}$ of soil from a cropland field (Haplic Luvisol [35], Beauvais, Northern France), by preparing a water extract with $200 \mathrm{~mL}$ of distilled water. The soil was not carbonated, contained $154 \mathrm{mg} \mathrm{g}^{-1}$ organic $\mathrm{C}, 18 \mathrm{mg} \mathrm{g}^{-1}$ total $\mathrm{N}$ and had a $\mathrm{pH}$ (water) of 7.7 (Table 1). After inoculum addition, $20 \mathrm{~g}$ of sample were placed in $100 \mathrm{~mL}$ glass vials and covered with rubber septa. We carried out the incubation in triplicate for 8 treatments ( 2 biochar/compost mixtures, a compost and one biochar (all fresh and weathered) at $20{ }^{\circ} \mathrm{C}$ 
during 12 months. As we hypothesized that pure biochars will behave similarly, we used only Miscanthus biochar as control sample. We adjusted the water content to $60 \%$ at the beginning of the incubation, when the flask's atmosphere was free of $\mathrm{CO}_{2}$. We monitored the decomposition of the materials by measuring release of $\mathrm{CO}_{2}-\mathrm{C}$ using a micro-GC (490 Micro-GC, Agilent Technologies, Les Ulis, France) and the stable carbon isotope ratio of $\mathrm{CO}_{2}-\mathrm{C}$ with an isotopic ratio mass spectrometer (Vario isotope select, Elementar, UK-Ltd, Cheadle, UK) at day 1,3, 7, 16, 24, and then once a month until the end of the incubation. At each $\mathrm{CO}_{2}-\mathrm{C}$ measurement date, we also determined the isotopic signature of the $\mathrm{CO}_{2}$ emitted by compost, biochar and compost-biochar mixtures. Thanks to the isotopic ${ }^{13} \mathrm{C}$ signature of the C4-biochar, which is distinctly different from C3 compost, we were able to determine the contribution of carbon mineralized from biochar or compost in $\mathrm{CO}_{2}$ emitted from the biochar-compost mixtures. After each measurement, we flushed the bottles with synthetic $\mathrm{CO}_{2}$ free-air. The results are expressed as cumulated $\mathrm{CO}_{2}-\mathrm{C}$ emitted form fresh and aged samples in terms of initial total $\mathrm{C}$ content of the compost or biochar within the fresh samples.

Table 1. Characteristics of the Calcaric Cambisol and Haplic Luvisol used for the pot experiment.

\begin{tabular}{cccc}
\hline & Unit (Dry Matter) & Calcaric Cambisol & Haplic Luvisol \\
\hline Clay & $\%$ & 33.3 & 17.6 \\
Silt & $\%$ & 46.1 & 66.9 \\
Sand & $\%$ & 20.6 & 15.6 \\
CaCO3 & $\mathrm{g} \mathrm{kg}^{-1}$ & 563.3 & 0.0 \\
organic C & $\mathrm{g} \mathrm{kg}^{-1}$ & 9.5 & 15.4 \\
total N & $\mathrm{g} \mathrm{kg}^{-1}$ & 2.6 & 1.8 \\
C/N & & 3.6 & 8.6 \\
pH KCl & & 7.8 & 7.4 \\
pH water & & 8.0 & 7.8 \\
CEC & $\mathrm{cmolc} \mathrm{kg}^{-1}$ & 14.0 & 12.5 \\
P water & $\mathrm{mg} \mathrm{kg}^{-1}$ & 1.2 & 3.9 \\
Available P & $\mathrm{mg} \mathrm{kg}^{-1}$ & 19.7 & 71.2 \\
Available K & $\mathrm{mg} \mathrm{kg}^{-1}$ & 326.8 & 291.9 \\
Available Mg & $\mathrm{mg} \mathrm{kg}^{-1}$ & 271.1 & 100.7 \\
Available Ca & $\mathrm{mg} \mathrm{kg}^{-1}$ & 46727.4 & 3868.6 \\
\hline
\end{tabular}

\subsection{Effect on Biomass Production: Pot Experiment}

A pot experiment was carried out with fresh and weathered compost and mixtures added to two different agricultural soils sampled in Beauvais (Northern France) and classified as a silt loam Haplic Luvisol and a clay loam Calcaric Cambisol [35]. Soil characteristics are shown in Table 1.

After sieving the soil $(4 \mathrm{~mm})$, the composts and mixtures were applied at respectively $16 \mathrm{tha}^{-1}$ and $20 \mathrm{t} \mathrm{ha}^{-1}$ to $0.4 \mathrm{~kg}$ of soil. Both fresh and weathered amendments were applied to soil at a similar rate, considering the mass loss during the weathering treatment. The pots were sown with $0.15 \mathrm{~g} \mathrm{pot}^{-1}$ of Italian ryegrass (Festuca perennis Lam. ex Lolium multiflorum) seeds. Thereafter, they were kept in a growth chamber under controlled conditions: $16 \mathrm{~h} \mathrm{day}^{-1}$ of light, a temperature of $24^{\circ} \mathrm{C}$ (day) and $20^{\circ} \mathrm{C}$ (night) and addition of distilled water every two days (Supplementary Material, Figure S2). We harvested the plants 4 weeks after sowing by cutting at $2 \mathrm{~cm}$ from soil surface. Biomass production was determined gravimetrically after $72 \mathrm{~h}$ drying at $60^{\circ} \mathrm{C}$.

\subsection{Calculations and Statistics}

The stable $\mathrm{C}$ isotope signatures were used to estimate the contribution of biochar and compost to the mixtures and the $\mathrm{CO}_{2}$ emissions from the mixtures. The partitioning was done with Equation (1):

$$
C_{\text {biochar,mix }}=\left(\delta^{13} C_{\text {mixture }}-\delta^{13} C_{\text {compost }}\right) /\left(\delta^{13} C_{\text {biochar }}-\delta^{13} C_{\text {compost }}\right)
$$


where $\mathrm{C}_{\text {biochar,mix }}$ is biochar carbon in the mixture or in $\mathrm{CO}_{2}-\mathrm{C}$ emitted from the mixture $(\%) ; \delta^{13} C_{\text {mixture }}$ is the stable $C$ isotope signature of the mixture, $\delta^{13} C_{\text {biochar }}$ is the stable $C$ isotope signature of biochar and $\delta^{13} \mathrm{C}_{\text {compost }}$ is the stable isotope signature of compost.

To evaluate interactions between biochar and compost in mixtures, we calculated expected values for the mixtures according to Equation (2). The comparison between the expected and the measured values of the mixtures were used to assess interactions between biochar and compost.

$$
\mathrm{m}_{\text {biochar,mix }} / \mathrm{m}_{\text {mixture }}=\mathrm{C}_{\text {mixture }} \times \mathrm{C}_{\text {biochar,mix }} / \mathrm{C}_{\text {biochar }}
$$

where $\mathrm{m}_{\text {biochar,mix }}$ is the mass of biochar within the mixture $(\mathrm{g}) ; \mathrm{m}_{\text {mixture }}$ is the mass of the mixture (g); $C_{\text {mixture }}$ is the $C$ content of the mixture; and $C_{\text {biochar }}$ is the $C$ content of biochar.

To calculate differences between fresh and weathered materials, we tested for normality using the Shapiro-Wilk test. For the normally distributed data, we performed analysis of variances (ANOVA) and Tukey multiple comparison. When data did not follow a normal distribution, we used Kruskal-Wallis tests with Bonferroni corrections. The level of significance was set at $p=0.05$. We performed all statistical analyses using the R software (version 3.5.2).

\section{Results}

\subsection{Leaching Due to Physical Weathering}

Material losses ranged from about $20 \mathrm{mg} \mathrm{g}^{-1}$ for maize biochar to about $150 \mathrm{mg} \mathrm{g}^{-1}$ for compost (Figure 1). Artificial physical weathering thus resulted in twice as much material loss from compost as compared to biochars. Mass losses for both mixtures were around $75 \mathrm{mg} \mathrm{g}^{-1}$. They were about two times lower than expected from the losses of individual materials (Figure 1).

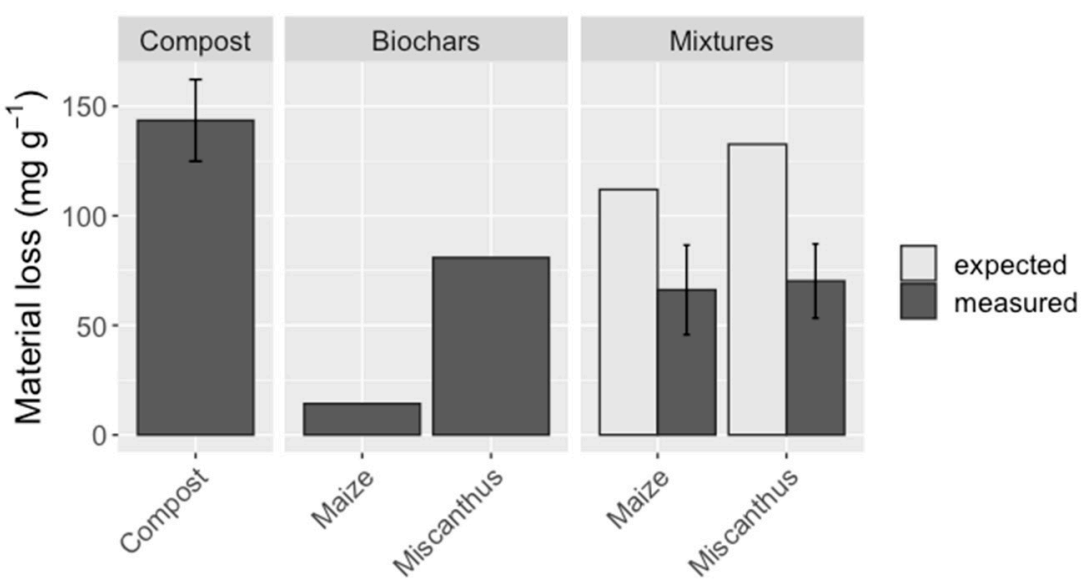

Figure 1. Total mass loss during physical weathering of compost, biochars and their mixtures. Data are presented as mean $\pm \mathrm{sd}$ ( $n=2$ for the compost and the mixture and $n=1$ for the biochars). Expected values for mixtures were calculated based on mass losses measured for individual components.

\subsection{Properties of the Fresh and Weathered Materials}

\subsubsection{Elemental Composition}

Fresh compost was composed of $226 \mathrm{mg} \mathrm{g}^{-1} \mathrm{C}, 20 \mathrm{mg} \mathrm{g}^{-1} \mathrm{H}, 112 \mathrm{mg} \mathrm{g}^{-1} \mathrm{O}$ and $23 \mathrm{mg} \mathrm{g}^{-1} \mathrm{~N}$ (Table 2). Fresh biochars contained at least twice more $\mathrm{C}$ than the fresh compost, with biochar from maize and Miscanthus containing respectively 591 and $778 \mathrm{mg} \mathrm{g}^{-1}$ $\mathrm{C}$ (Table 2). Hydrogen content of biochars were similar to compost, whereas $\mathrm{O}$ and $\mathrm{N}$ content of biochars were at least twice lower than for compost. Following the mixing ratio, carbon content of the mixtures ranged between $298 \mathrm{mg} \mathrm{g}^{-1}$ and $332 \mathrm{mg} \mathrm{g}^{-1}$ and all other elemental components had similar values for both mixtures. The mixtures showed similar $\mathrm{C} / \mathrm{N}$ ratios independently from biochar feedstocks. 
Table 2. Elemental composition of fresh $(\mathrm{F})$ and weathered $(\mathrm{W})$ compost, biochars and biocharcompost mixtures. Expected (exp) values were calculated for the weathered mixtures. Data are presented as means $\pm \mathrm{sd}(n=3)$. The letters represent differences among treatments.

\begin{tabular}{|c|c|c|c|c|c|c|c|}
\hline & & & $C\left(\mathrm{mg} \mathrm{g}^{-1}\right)$ & $H\left(\mathrm{mg} \mathrm{g}^{-1}\right)$ & $O\left(\mathrm{mg} \mathrm{g}^{-1}\right)$ & $N\left(\mathrm{mg} \mathrm{g}^{-1}\right)$ & $\mathrm{C} / \mathrm{N}$ \\
\hline \multicolumn{8}{|l|}{ Compost } \\
\hline \multirow[t]{2}{*}{ Compost } & $\mathrm{F}$ & & $226 \pm 1^{\mathrm{i}}$ & $20 \pm 1^{a b}$ & $112 \pm 4^{a}$ & $23 \pm 0^{a}$ & $10 \pm 0^{g}$ \\
\hline & W & & $209 \pm 5^{j}$ & $17 \pm 5^{\mathrm{abc}}$ & $99 \pm 4^{\mathrm{b}}$ & $21 \pm 1^{\mathrm{ab}}$ & $10 \pm 0 \mathrm{~g}$ \\
\hline \multicolumn{8}{|l|}{ Biochars } \\
\hline \multirow[t]{2}{*}{ Maize } & $\mathrm{F}$ & & $591 \pm 1^{d}$ & $21 \pm 1^{\mathrm{ab}}$ & $48 \pm 3^{d}$ & $8 \pm 0$ gh & $72 \pm 0^{c}$ \\
\hline & W & & $618 \pm 0^{\mathrm{c}}$ & $21 \pm 0^{\mathrm{ab}}$ & $76 \pm 5^{c}$ & $9 \pm 0 \mathrm{fg}$ & $65 \pm 0^{\mathrm{d}}$ \\
\hline \multirow[t]{2}{*}{ Miscanthus } & $\mathrm{F}$ & & $778 \pm 1^{\mathrm{a}}$ & $13 \pm 1^{\mathrm{c}}$ & $18 \pm 3^{e}$ & $4 \pm 0 \mathrm{hi}$ & $186 \pm 0^{b}$ \\
\hline & $\mathrm{W}$ & & $742 \pm 1^{b}$ & $16 \pm 2^{b c}$ & $58 \pm 6^{d}$ & $4 \pm 0^{\mathrm{i}}$ & $189 \pm 0.3^{a}$ \\
\hline \multicolumn{8}{|l|}{ Mixtures } \\
\hline \multirow[t]{3}{*}{ Maize } & $\mathrm{F}$ & & $298 \pm 3^{h}$ & $19 \pm 1^{a b}$ & $103 \pm 0^{\mathrm{ab}}$ & $17 \pm 0$ ef & $17 \pm 0^{\mathrm{f}}$ \\
\hline & $\mathrm{W}$ & & $350 \pm 3^{f}$ & $22 \pm 1^{\mathrm{a}}$ & $78 \pm 1^{\mathrm{c}}$ & $18 \pm 0^{\mathrm{cd}}$ & $20 \pm 0$ ef \\
\hline & & $\exp$ & 321 & 18 & 92 & 18 & 18 \\
\hline \multirow[t]{3}{*}{ Miscanthus } & $\mathrm{F}$ & & $332 \pm 1^{\mathrm{g}}$ & $19 \pm 2^{a b}$ & $107 \pm 3^{\mathrm{ab}}$ & $19 \pm 0 \mathrm{bc}$ & $17 \pm 0^{\mathrm{f}}$ \\
\hline & $\mathrm{W}$ & & $374 \pm 3^{\mathrm{e}}$ & $20 \pm 1^{a b}$ & $83 \pm 1^{c}$ & $17 \pm 0$ de & $22 \pm 0^{\mathrm{e}}$ \\
\hline & & $\exp$ & 355 & 16 & 87 & 16 & 22 \\
\hline
\end{tabular}

Compost weathering induced decreasing contents of all elements, while mostly $\mathrm{C}$ and $\mathrm{O}$ were affected for biochars. As a result of weathering, $\mathrm{C}$ content respectively increased and decreased for the maize and Miscanthus biochars, while O content more than doubled for both biochars. The expected $\mathrm{C}$ content of the weathered mixtures were slightly lower than the measured ones ranging between 321 and 355. As for biochars, weathering affected mainly the $\mathrm{C}$ and $\mathrm{O}$ contents of the mixtures; $\mathrm{O}$ contents of the weathered mixtures were slightly lower than the expected values. For both mixtures, weathering increased the $\mathrm{C} / \mathrm{N}$ ratio (Table 2).

\subsubsection{Physico-Chemical Properties, Dissolved Organic Carbon and Stable $\delta^{13} \mathrm{C}$ Ratio}

Table 3 shows physico-chemical properties and the dissolved organic carbon content (DOC) of the materials. $\mathrm{pH}$ and electrical conductivity (EC) ranged from 8.1 to 10.5 and from 109 to $1598 \mu \mathrm{S} \mathrm{cm}^{-1}$, respectively. Compost had lower $\mathrm{pH}(8.4)$, and EC $\left(944 \mu \mathrm{S} \mathrm{cm}{ }^{-1}\right)$ than both biochars. Both biochars showed similar $\mathrm{pH}$ (around 10.5), but maize biochar had higher EC than Miscanthus biochar. The $\mathrm{pH}$ and EC of fresh mixtures were in between the values from compost and biochars.

Fixed C content ranged between 0.6 and $67.8 \%$, DOC varied between 2.2 and $277.2 \mathrm{mg} \mathrm{g}^{-1} \mathrm{C}$, whereas ash content ranged between 13.6 and $59.3 \%$ and volatile matter content between 17.8 and $38.8 \%$. Compost showed lower fixed C and higher DOC, ash content and volatile matter than biochars. Both biochars had similar volatile $\mathrm{C}$ but varied in ash content and fixed C; maize biochar presented a twice-higher ash content and a lower fixed C content ( 45.6 vs. $63.6 \%$ ) than Miscanthus biochar. We assumed that differences between the two biochars were mainly driven by production temperature rather than initial feedstock, as it has been found to be the main driver of biochar chemical composition [36-38]. Maize mixtures showed higher $\mathrm{pH}(9.1$ vs. 8.9) and ash contents (54.0 vs. $51.2 \%$ ) and lower volatile matter contents ( 35.1 vs. $38.2 \%$ ) compared to Miscanthus mixture.

Weathering induced an increase of fixed $C$ from around $10 \%$ to $17.1 \%$ and $16.6 \%$ for maize and Miscanthus mixtures. In contrast, EC and DOC showed 4 times lower values after weathering. When compared to the expected values, slightly higher EC values than expected were recorded for both mixtures after weathering. In addition, the weathered mixture with maize biochar showed lower DOC (50.1 vs. $57.6 \mathrm{mg} \mathrm{g} \mathrm{C}^{-1}$ ) and higher fixed C (17.1 vs. $11.6 \%)$ than expected. The weathered Miscanthus mixture showed higher volatile matter than expected (37.1 vs. 31.3\%) (Table 3). During weathering, the isotopic signatures 
remained unchanged for compost, biochars and the mixture containing maize biochar, but decreased for the mixture containing Miscanthus biochar. The $\delta^{13} \mathrm{C}$ ratios of the weathered mixtures $(21.9 \%$ o ) were lower than expected (25.4 and $25.2 \%$ o).

Table 3. Chemical characteristics of fresh (F) and weathered (W) compost, biochars and biochar-compost mixtures. Expected (exp.) values were calculated for the weathered mixtures. EC: electric conductivity; DOC: dissolved organic carbon. Data are presented as means $\pm \mathrm{sd}(n=3)$ for $\mathrm{pH}, \mathrm{EC}$, DOC and $\delta^{13} \mathrm{C}$. Proximate analysis was carried out for 1 sample. The letters represent differences among treatments.

\begin{tabular}{|c|c|c|c|c|c|c|c|c|c|}
\hline & & & $\mathrm{pH}^{*}$ & $\mathrm{EC}\left(\mu \mathrm{S} \mathrm{cm}{ }^{-1}\right)$ & $\mathrm{DOC}\left(\mathrm{mg} \mathrm{g}^{-1} \mathrm{C}\right)$ & $\delta^{13} \mathrm{C}(\%)$ & $\begin{array}{l}\text { Ash } \\
(\%)\end{array}$ & $\begin{array}{c}\text { Volatile } \\
(\%)\end{array}$ & $\begin{array}{c}\text { Fixed C } \\
(\%)\end{array}$ \\
\hline \multicolumn{10}{|l|}{ Compost } \\
\hline \multirow[t]{2}{*}{ Compost } & $\mathrm{F}$ & & $8.4^{\mathrm{g}}$ & $944 \pm 18^{\mathrm{cd}}$ & $277.2 \pm 49.0^{\mathrm{a}}$ & $-28.9 \pm 0.1$ gh & 59.3 & 38.8 & 1.9 \\
\hline & $\mathrm{W}$ & & $7.9^{\mathrm{h}}$ & $215 \pm 4^{\mathrm{fg}}$ & $73.5 \pm 2.4^{\mathrm{cd}}$ & $-29.2 \pm 0.0^{\mathrm{h}}$ & 63.0 & 36.4 & 0.6 \\
\hline \multicolumn{10}{|l|}{ Biochars } \\
\hline \multirow[t]{2}{*}{ Maize } & $\mathrm{F}$ & & $10.5^{a}$ & $1640 \pm 62^{a}$ & $36.7 \pm 1.6^{\mathrm{f}}$ & $-15.3 \pm 0.1 \mathrm{bc}$ & 28.5 & 25.9 & 45.6 \\
\hline & W & & $8.7^{\mathrm{e}}$ & $109 \pm 3^{g}$ & $15.5 \pm 0.1^{\mathrm{fg}}$ & $-15.3 \pm 0.0^{c}$ & 23.5 & 35.7 & 40.8 \\
\hline \multirow[t]{2}{*}{ Miscanthus } & $\mathrm{F}$ & & $10.4^{\mathrm{a}}$ & $1516 \pm 14^{b c}$ & $3.6 \pm 0.7 \mathrm{~g}$ & $-14.9 \pm 0.1^{\mathrm{ab}}$ & 13.6 & 22.8 & 63.6 \\
\hline & W & & $9.4^{b}$ & $129 \pm 3 g$ & $2.2 \pm 0.1 \mathrm{~g}$ & $-14.5 \pm 0.1^{\mathrm{a}}$ & 14.4 & 17.8 & 67.8 \\
\hline \multicolumn{10}{|l|}{ Mixtures } \\
\hline \multirow[t]{3}{*}{ Maize } & $\mathrm{F}$ & & $9.1^{\mathrm{c}}$ & $1588 \pm 12^{a b}$ & $203.2 \pm 7.9 \mathrm{bc}$ & $-22.3 \pm 0.3^{\mathrm{ef}}$ & 54.0 & 35.1 & 10.9 \\
\hline & W & real & $8.6^{\mathrm{e}}$ & $224 \pm 3^{\text {ef }}$ & $50.1 \pm 1.1$ ef $^{-1}$ & $-21.9 \pm 0.0^{\mathrm{de}}$ & 48.9 & 34.0 & 17.1 \\
\hline & & $\exp$ & 8.1 & 186 & 57.6 & -25.4 & 52.2 & 36.2 & 11.6 \\
\hline \multirow[t]{3}{*}{ Miscanthus } & $\mathrm{F}$ & & $8.9^{\mathrm{d}}$ & $1598 \pm 20^{a}$ & $210.3 \pm 9.3^{\mathrm{ab}}$ & $-23.2 \pm 0.1^{\mathrm{fg}}$ & 51.2 & 38.2 & 10.6 \\
\hline & W & real & $8.5^{\mathrm{f}}$ & $238 \pm 15^{\mathrm{de}}$ & $54.3 \pm 1.5^{\mathrm{de}}$ & $-21.9 \pm 0.1^{\mathrm{d}}$ & 46.3 & 37.1 & 16.6 \\
\hline & & $\exp$ & 8.3 & 192 & 54.0 & -25.2 & 49.7 & 31.3 & 19.0 \\
\hline
\end{tabular}

${ }^{*}$ standard deviations of $\mathrm{pH}$ were $<0.05$.

\subsection{Biological Stability}

Cumulative $\mathrm{CO}_{2}-\mathrm{C}$ released during 1-year of incubation from fresh and weathered compost, Miscanthus biochar and both mixtures are presented in Figure 2. After 1 year of incubation, the fresh compost showed the highest cumulative $C$ mineralization with values up to $30 \mathrm{mg} \mathrm{g}^{-1}$ of initial carbon. In contrast, very few $C$ was mineralized from Miscanthus biochar. The isotopic signatures of carbon were used to assess the origin of $\mathrm{C}$ mineralized from biochar-compost mixtures. The data indicated that compost released between 15 and $20 \mathrm{mg} \mathrm{g}^{-1} \mathrm{C}$ when incubated in mixtures, while biochar released between 10 and $15 \mathrm{mg} \mathrm{g}^{-1} \mathrm{C}$ when incubated in mixtures. Compost showed lower $\mathrm{C}$-mineralization in mixture compared to individual incubation. Conversely, biochar showed higher Cmineralization when combined with compost compared to individual incubation.

After weathering, cumulative compost $C$ mineralization amounted to $10 \mathrm{mg} \mathrm{g}^{-1} \mathrm{C}$, which was significantly lower than $C$ mineralization of fresh compost (Figure 2). Biochar C-mineralization was not significantly affected by weathering when individually incubated. When combined with compost it mineralized significantly less than in fresh mixtures. In contrast, compost mineralized significantly more in weathered mixtures as compared to fresh mixtures and reached values between 20 and $25 \mathrm{mg} \mathrm{g}^{-1} \mathrm{C}$ after 1-year incubation.

\subsection{Ryegrass Growth}

Biomass of Italian ryegrass was higher when grown on Haplic Luvisol as compared to Calcaric Cambisol, as shown for the unamended controls (Figure 3). All organic amendments stimulated ryegrass growth, when applied to Calcaric Cambisol. However, when applied to Haplic Luvisol, organic amendments induced neutral or negative effects on biomass. For both soils, application of fresh biochar-compost mixtures did not lead to significant differences in ryegrass biomass as compared to fresh compost alone. Physical weathering decreased the effect of compost addition to Calcaric Cambisol on biomass, but 
the effect was still positive as compared to the control. Concerning the Haplic Luvisol, compost addition tended to decrease biomass. For both soils and after weathering, the mixture containing Miscanthus biochar induced significantly higher biomass than the compost alone, while the mixture containing maize biochar showed similar effects as compost alone.

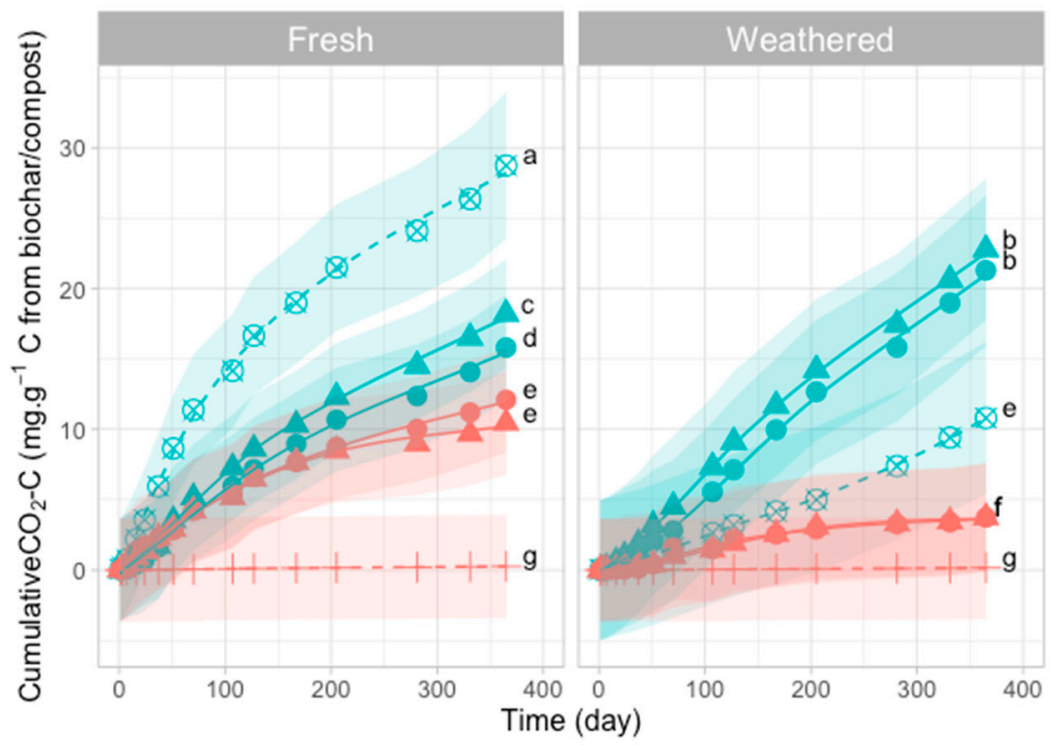

\section{Media}

Compost (Com)

- Com + Maize biochar

- Com + Miscanthus biochar

+ Miscanthus biochar

Origin of $\mathrm{CO}_{2}-\mathrm{C}$

Biochar

Compost

Figure 2. Cumulative $\mathrm{CO}_{2}-\mathrm{C}$ mineralized from biochar and compost when incubated alone or in mixture. Turquoise and red colors represent $\mathrm{C}$ mineralized from compost and biochar respectively. Data represent means from 3 replicated samples. The colored ribbon represents the standard deviations. The letters represent the significant differences from a two-ways ANOVA analysis $(n=3)$.

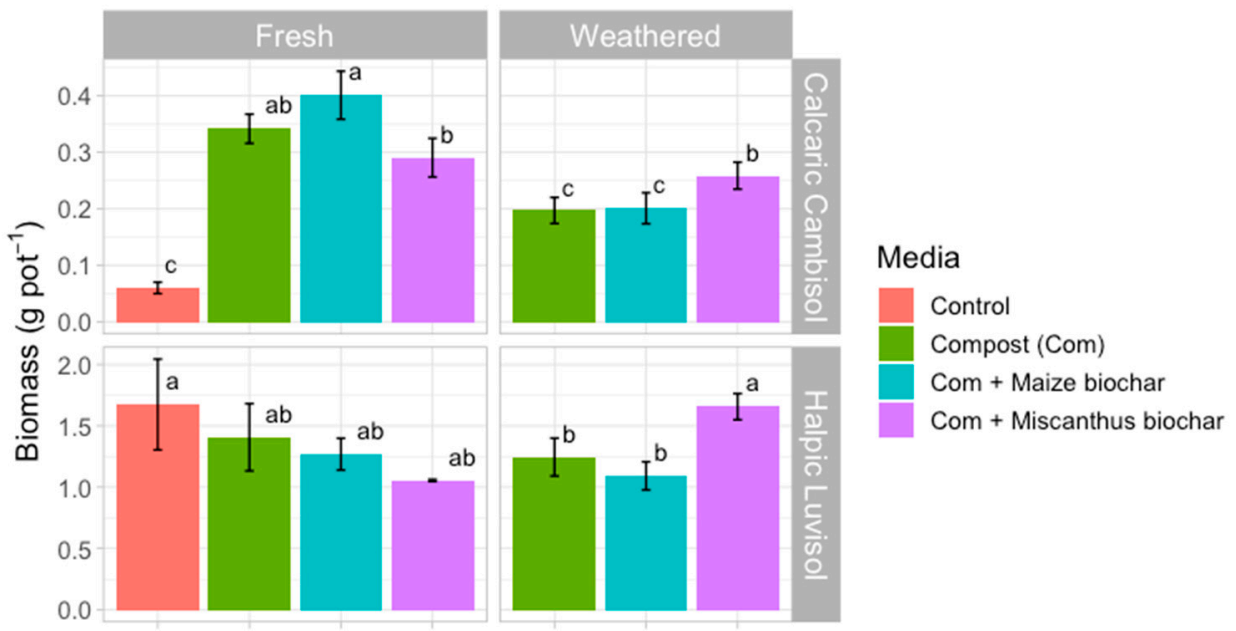

Figure 3. Biomass of ryegrass after addition of compost or its mixture with maize and Miscanthus biochars, grown on two soil types. Data are presented as means $\pm \mathrm{sd}(n=3)$. The letters represent the significant differences from a one-way ANOVA analysis $(n=4)$ within each treatment and soil type.

\section{Discussion}

\subsection{Weathering Effects on Material Properties}

Physical weathering induced much higher mass loss from compost as compared to biochar and mixtures. This may probably be explained by the high leaching losses. Biochar mass loss amounted to $75 \mathrm{mg} \mathrm{g}^{-1}$, which is much lower than observed for gasification biochar [29]. This may be due to the lower friability of biochar produced by pyrolysis making it less prone to particle losses [30]. Lower mass loss for the mixtures than ex- 
pected (Figure 1), may be explained by protection of compost from leaching losses by its association with the biochar structure $[12,39]$. Both weathering cycles may affect release of dissolved organic matter and cause cracking on biochar-surfaces, thus leading to changes in pore structure [40]. While DOC was lower than expected in weathered mixtures, EC values were higher than expected (see below). We therefore suggest that there may be interactions between biochar and compost leading to solid particles retention during weathering treatment.

Compost weathering induced a decrease of the content of all main elements, following strong leaching due to weathering treatment (Table 2). However, weathering of biochars affected only $\mathrm{C}$ and $\mathrm{O}$ contents and led to decreasing $\mathrm{C}$ content and increasing $\mathrm{O}$ content. Our results are consistent with data of Naisse et al. [29], who suggested that these observations may indicate oxidation processes induced by weathering [41]. In contrast, weathering of the mixtures increased their $\mathrm{C}$ contents, while it decreased their $\mathrm{O}$ contents. This might be related to a preferential elimination of $O$ relative to $C$ in the labile fraction of the mixtures. This hypothesis may be supported by the visual observation of high loss of soluble compounds during weathering. Indeed, strong decreases of DOC and EC of the remaining substrates indicated that soluble compounds were removed by leaching during artificial weathering (Table 3). In contrast to the mixture containing Miscanthus biochar, the DOC content of the mixture containing maize biochar decreased slightly stronger than expected. The strong decrease of EC as a result of weathering is consistent with the results of Yao et al. [42], who evidenced a rapid decline of EC from 0.7 to $0.2 \mathrm{mS} \mathrm{cm}^{-1}$ following leaching losses from biochar. EC reduction after weathering may be due to the leaching of mineral biochar compounds. This is supported by the lower ash content of the material remaining after weathering. Ashes and volatile compounds were both partly removed during weathering, except for volatile compounds of maize biochar. Both ashes and volatile compounds compose the labile fraction of all materials and are more likely to be leached than the more stable compounds. In particular, ash represents the mineral material contribution, which may be an indicator of nutrient content [43].

Fixed C slightly decreased for compost and biochars following weathering treatment, while it increased for the mixtures (Table 3 ). Fixed $C$ is mainly composed by fused aromatic $C$ structures and may be used as an indicator of the $C$ sequestration potential of biochars [44]. Higher fixed $C$ of the mixtures than the expected values after weathering might result from the increasing chemical recalcitrance of the materials due to labile compounds leaching. These observations are in agreement with the lower than expected $\delta^{13} \mathrm{C}$ ratios of the mixtures, might indicate preferential leaching of ${ }^{12} \mathrm{C}$ enriched compounds, e.g., C3-compost or labile polysaccharides, which are ${ }^{13} \mathrm{C}$ enriched compared to recalcitrant compounds [45].

\subsection{Biological Stability}

\subsubsection{Biological Stability of the Fresh Materials}

During the incubation, compost showed the highest cumulative C-mineralization, while biochar $C$ hardly mineralized. C-mineralization of the mixtures ranged between those of its individual components. These results are in agreement with other studies $[13,14,16]$ and may be explained by a higher content of labile $C$ in compost than in biochar [5]. It was interesting to note that compost showed a lower C-mineralization when combined with biochar than when incubated individually. Two mechanisms could explain observation: the adsorption of labile fraction on the biochar surface [13], and the presence of phenolic compounds or salts originating from biochar $[24,25,27]$, which might inhibit microbial activity in compost-biochar mixtures. The opposite effect was observed for biochar, since biochar $\mathrm{C}$ mineralized more when combined with compost than when individually applied. Indeed, several studies showed positive priming effect when labile substrates were added to biochar [46-48]. 


\subsubsection{Effect of Weathering on the Biological Stability}

The cumulative C-mineralization from compost after 1 year of incubation was significantly lower for weathered compost compared to fresh compost when individually incubated (10 vs. $30 \mathrm{mg} \mathrm{g}^{-1}$ ). This negative effect of weathering on C-mineralization from compost was attributed to the strong leaching of easily mineralizable labile components. On the other hand, the absence of weathering effects on biochar $\mathrm{C}$ mineralisation may be explained by the high stability of biochar with only few labile compounds [48].

C-mineralization from compost in the mixture increased significantly after weathering, when compared to the fresh mixtures (Figure 2). This may be due to the protection of labile compounds by biochar and/or the removal of biochar compounds, which inhibited microbial activity and thus C-mineralization from compost (see above). Indeed, fresh biochar may contain large amounts of salts, which may inhibit microbial activity when applied to soil [49-51]. This could lead to the negative priming effect of biochar on native C often observed immediately after soil addition [52].

Weathering also reduced biochar C-mineralization, within the mixtures (Figure 2), most probably due to the leaching of easily mineralizable $C$ and nutrients from compost, which stimulated biochar C-mineralization before weathering (see above). Our results thus indicate that weathering affects biochar-compost interaction in mixtures, which might also impact their effects on plant growth.

\subsection{Ryegrass Growth}

\subsubsection{Effect of the Fresh Media on Ryegrass Growth}

Higher ryegrass biomass was recorded when grown on Haplic Luvisol as compared to Calcaric Cambisol, regardless the organic amendment (Figure 3). Moreover, the addition of organic amendments containing compost had positive effects on biomass when applied on Calcaric Cambisol, but the effects were neutral or negative when applied to Haplic Luvisol (Figure 3). Our results were consistent with the results of Von Glisczynski et al. [53], who also did not find any plant growth promoting effect of biochar-compost mixtures application on Haplic Luvisol. As reviewed by Faucon et al. [54], organic amendments such as compost may promote plant growth by providing readily available nutrients or releasing them through mineralization. The available $P$ concentration of the Calcaric Cambisol was much lower than that of the Haplic Luvisol (19.66 vs. $71.18 \mathrm{mg} \mathrm{kg}^{-1}$ ) (Table 1), suggesting a possible P-limitation for plant growth in this soil, which might have been alleviated by compost application.

Addition of biochar compost mixtures led to similar ryegrass biomass than compost along (Figure 3). As reported in the literature, the combination of biochar with compost can have synergic $[32,55]$, antagonistic $[23,56]$ or neutral effects $[16,18,23,57,58]$ on plant growth. Several factors may impact plant growth after biochar-compost mixtures addition and the mechanisms are still poorly understood [17]. It was suggested that pre-treatment of biochar may be beneficial for plant growth before its soil application [59]. Moreover, it was shown that weathering may alter biochar properties [29]. Therefore, we tested in the following, if weathering of biochar/compost mixtures influenced plant growth.

\subsubsection{Effect of Weathered Amendments on Ryegrass Growth}

Irrespective of the soil type, weathered compost had negative or neutral effects on biomass when individually applied (Figure 3). This is most likely due to the weatheringinduced loss of readily-available nutrients and easily-mineralizable C compounds (Table 3 and Figure 2).

The addition of weathered biochar-compost mixtures to both soils had neutral or positive effects on biomass compared to the effect of compost applied individually depending on the biochar feedstock (Figure 3). The positive effect of the weathered Miscantus mixture on biomass may result from better compost mineralisation through the removal of compounds, which inhibit microbial activity as discussed above (Section 4.3.1). However, the weathered maize mixture showed neutral effect on biomass when compared to the effects 
of weathered compost alone. Our results showed that weathering of biochar-compost mixtures could lead to positive growth effect. These results are in agreement with a recent field study, showing positive growth effects on the second crop after soil application [60]. In addition, our results also showed that neutral effects of weathering depending on biochar feedstocks and/or soil type may occur $[60,61]$. Further studies would be needed to investigate the mechanisms controlling the variation of biochar-compost interactions on plant growth over time.

\section{Conclusions}

We investigated the effect of two biochar-compost mixtures and weathering on their material properties, biological stability and on plant growth after addition to two contrasting soils. Our results showed that the physical weathering led to the alteration of material properties of the mixtures, in particular through leaching of labile compounds. These effects could impact the mineralisation of the mixture and also plant growth after soil addition. We suggest that the mixtures contained inhibitive compounds for microbial activity in their labile fraction, as shown by the negative effect on compost mineralisation when combined with biochar. The increase of compost mineralisation within the mixtures after weathering may have provided more plant available nutrients, which could promote plant biomass production when compared to individual compost application. On the other hand, biochar mineralisation was also affected by weathering, indicating that weathering may influence its $C$ sequestration potential.

We conclude that biochar-compost interactions are evolving after physical weathering most probably due to its effect on leaching of soluble compounds. The effect of fresh and weathered biochar-compost mixtures on plant growth depend on biochar production conditions. Further studies should focus on mechanisms influencing the nutrient supply of biochar-compost mixtures.

Supplementary Materials: The following are available online at https:/ /www.mdpi.com/2073-439 5/11/2/336/s1, Figure S1: Experimental set up used for physical weathering of organic amendments, Figure S2: Pot experiment with ryegrass.

Author Contributions: M.-L.A., C.G., S.H., C.N., D.H. and C.R. designed the study. M.-L.A. and C.N. carried out the laboratory work, and exploited the results. Y.L.B. and S.B. contributed data. M.-L.A. wrote the first draft of the manuscript. All authors discussed the results and commented on the manuscript. All authors have read and agreed to the published version of the manuscript.

Funding: The study was funded by FUI (project BIOCHAR21). ADEME provided a PhD grant.

Data Availability Statement: Data will be made available upon request.

Acknowledgments: We thank FUI for funding under the framework of the project BIOCHAR21. MLA acknowledges ADEME for providing her PhD grant. We thank Valérie Pouteau for help with the laboratory work.

Conflicts of Interest: The authors declare no conflict of interest.

\section{References}

1. Field, C.B.; Barros, V.R.; Mastrandrea, M.D.; Mach, K.J.; Abdrabo, M.A.-K.; Adger, N.; Anokhin, Y.A.; Anisimov, O.A.; Arent, D.J.; Barnett, J.; et al. Summary for Policymakers. Available online: https:/ / epic.awi.de/id/eprint/37531/ (accessed on 4 February 2021).

2. Smith, P. Soil carbon sequestration and biochar as negative emission technologies. Glob. Chang. Biol. 2016, 22, 1315-1324. [CrossRef] [PubMed]

3. Abbott, L.; Macdonald, L.; Wong, M.; Webb, M.; Jenkins, S.; Farrell, M. Potential roles of biological amendments for profitable grain production-A review. Agric. Ecosyst. Environ. 2018, 256, 34-50. [CrossRef]

4. Lehmann, J.; Joseph, S. (Eds.) Biochar for Environmental Management. Science, Technology and Implementation; Routledge: London, UK, 2015.

5. Liu, W.-J.; Jiang, H.; Yu, H.-Q. Development of Biochar-Based Functional Materials: Toward a Sustainable Platform Carbon Material. Chem. Rev. 2015, 115, 12251-12285. [CrossRef] [PubMed]

6. Glaser, B.; Lehmann, J.; Zech, W. Ameliorating physical and chemical properties of highly weathered soils in the tropics with charcoal-A review. Biol. Fertil. Soils 2002, 35, 219-230. [CrossRef] 
7. Alghamdi, A.G. Biochar as a potential soil additive for improving soil physical properties-A review. Arab. J. Geosci. 2018, 11, 766. [CrossRef]

8. Paetsch, L.; Mueller, C.W.; Kögel-Knabner, I.; Von Lützow, M.; Girardin, C.; Rumpel, C. Effect of in-situ aged and fresh biochar on soil hydraulic conditions and microbial C use under drought conditions. Sci. Rep. 2018, 8, 1-11. [CrossRef]

9. Obia, A.; Mulder, J.; Martinsen, V.; Cornelissen, G.; Børresen, T. In situ effects of biochar on aggregation, water retention and porosity in light-textured tropical soils. Soil Tillage Res. 2016, 155, 35-44. [CrossRef]

10. Sun, F.; Lu, S. Biochars improve aggregate stability, water retention, and pore-space properties of clayey soil. J. Plant. Nutr. Soil Sci. 2013, 177, 26-33. [CrossRef]

11. Barthod, J.; Rumpel, C.; Dignac, M.-F. Composting with additives to improve organic amendments. A review. Agron. Sustain. Dev. 2018, 38, 17. [CrossRef]

12. Jien, S.-H.; Wang, C.-C.; Lee, C.-H.; Lee, T.-Y. Stabilization of Organic Matter by Biochar Application in Compost-amended Soils with Contrasting $\mathrm{pH}$ Values and Textures. Sustainability 2015, 7, 13317-13333. [CrossRef]

13. Ngo, P.-T.; Rumpel, C.; Ngo, Q.-A.; Alexis, M.; Vargas, G.V.; Gil, M.D.L.L.M.; Dang, D.-K.; Jouquet, P.; Ngô, Q.-A. Biological and chemical reactivity and phosphorus forms of buffalo manure compost, vermicompost and their mixture with biochar. Bioresour. Technol. 2013, 148, 401-407. [CrossRef]

14. Jien, S.H.; Chen, W.C.; Ok, Y.S.; Awad, Y.M.; Liao, C.S. Short-term biochar application induced variations in C and N mineralization in a compost-amended tropical soil. Environ. Sci. Pollut. Res. 2018, 25, 25715-25725. [CrossRef]

15. Qayyum, M.F.; Liaquat, F.; Rehman, R.A.; Gul, M.; ul Hye, M.Z.; Rizwan, M.; ur Rehaman, M.Z. Effects of co-composting of farm manure and biochar on plant growth and carbon mineralization in an alkaline soil. Environ. Sci. Pollut. Res. 2017, 24, 26060-26068. [CrossRef] [PubMed]

16. Teutscherova, N.; Vazquez, E.; Santana, D.; Navas, M.; Masaguer, A.; Benito, M. Influence of pruning waste compost maturity and biochar on carbon dynamics in acid soil: Incubation study. Eur. J. Soil Biol. 2017, 78, 66-74. [CrossRef]

17. Agegnehu, G.; Srivastava, A.; Bird, M.I. The role of biochar and biochar-compost in improving soil quality and crop performance: A review. Appl. Soil Ecol. 2017, 119, 156-170. [CrossRef]

18. Trupiano, D.; Cocozza, C.; Baronti, S.; Amendola, C.; Vaccari, F.P.; Lustrato, G.; Di Lonardo, S.; Fantasma, F.; Tognetti, R.; Scippa, G.S. The Effects of Biochar and Its Combination with Compost on Lettuce (Lactuca Sativa L.) Growth, Soil Properties, and Soil Microbial Activity and Abundance. Available online: https:/ /www.hindawi.com/journals/ija/2017/3158207/ (accessed on 25 May 2020).

19. Naeem, M.A.; Khalid, M.; Aon, M.; Abbas, G.; Amjad, M.; Murtaza, B.; Khan, W.; Ahmad, N. Combined application of biochar with compost and fertilizer improves soil properties and grain yield of maize. J. Plant. Nutr. 2018, 41, 112-122. [CrossRef]

20. Manolikaki, I.; Diamadopoulos, E. Positive Effects of Biochar and Biochar-Compost on Maize Growth and Nutrient Availability in Two Agricultural Soils. Commun. Soil Sci. Plant. Anal. 2019, 50, 512-526. [CrossRef]

21. Zulfiqar, F.; Younis, A.; Chen, J. Biochar or Biochar-Compost Amendment to a Peat-Based Substrate Improves Growth of Syngonium podophyllum. Agronomy 2019, 9, 460. [CrossRef]

22. Tsai, C.-C.; Chang, Y.-F. Carbon Dynamics and Fertility in Biochar-Amended Soils with Excessive Compost Application. Agronomy 2019, 9, 511. [CrossRef]

23. Seehausen, M.L.; Gale, N.V.; Dranga, S.; Hudson, V.; Liu, N.; Michener, J.; Thurston, E.; Williams, C.; Smith, S.M.; Thomas, S.C. Is There a Positive Synergistic Effect of Biochar and Compost Soil Amendments on Plant Growth and Physiological Performance? Agronomy 2017, 7, 13. [CrossRef]

24. Gale, N.V.; Sackett, T.E.; Thomas, S.C. Thermal treatment and leaching of biochar alleviates plant growth inhibition from mobile organic compounds. PeerJ 2016, 4, e2385. [CrossRef] [PubMed]

25. Kołtowski, M.; Oleszczuk, P. Toxicity of biochars after polycyclic aromatic hydrocarbons removal by thermal treatment. Ecol. Eng. 2015, 75, 79-85. [CrossRef]

26. Buss, W.; Mašek, O. Mobile organic compounds in biochar-A potential source of contamination-Phytotoxic effects on cress seed (Lepidium sativum) germination. J. Environ. Manag. 2014, 137, 111-119. [CrossRef]

27. Deenik, J.L.; McClellan, T.; Uehara, G.; Antal, M.J.; Campbell, S. Charcoal Volatile Matter Content Influences Plant Growth and Soil Nitrogen Transformations. Soil Sci. Soc. Am. J. 2010, 74, 1259-1270. [CrossRef]

28. Ngo, P.T.; Rumpel, C.; Janeau, J.-L.; Dang, D.-K.; Doan, T.T.; Jouquet, P. Mixing of biochar with organic amendments reduces carbon removal after field exposure under tropical conditions. Ecol. Eng. 2016, 91, 378-380. [CrossRef]

29. Naisse, C.; Girardin, C.; Lefevre, R.; Pozzi, A.; Maas, R.; Stark, A.; Rumpel, C. Effect of physical weathering on the carbon sequestration potential of biochars and hydrochars in soil. GCB Bioenergy 2015, 7, 488-496. [CrossRef]

30. Spokas, K.A.; Novak, J.M.; Masiello, C.A.; Johnson, M.G.; Colosky, E.C.; Ippolito, J.A.; Trigo, C. Physical Disintegration of Biochar: An Overlooked Process. Environ. Sci. Technol. Lett. 2014, 1, 326-332. [CrossRef]

31. Prodana, M.; Bastos, A.; Amaro, A.; Cardoso, D.; Morgado, R.; Machado, A.; Verheijen, F.; Keizer, J.; Loureiro, S. Biomonitoring tools for biochar and biochar-compost amended soil under viticulture: Looking at exposure and effects. Appl. Soil Ecol. 2019, 137, 120-128. [CrossRef]

32. Doan, T.T.; Henry-Des-Tureaux, T.; Rumpel, C.; Janeau, J.-L.; Jouquet, P. Impact of compost, vermicompost and biochar on soil fertility, maize yield and soil erosion in Northern Vietnam: A three year mesocosm experiment. Sci. Total. Environ. 2015, 514, 147-154. [CrossRef] 
33. Schmidt, H.-P.; Kammann, C.; Niggli, C.; Evangelou, M.W.; Mackie, K.A.; Abiven, S. Biochar and biochar-compost as soil amendments to a vineyard soil: Influences on plant growth, nutrient uptake, plant health and grape quality. Agric. Ecosyst. Environ. 2014, 191, 117-123. [CrossRef]

34. Nobile, C.; Denier, J.; Houben, D. Linking biochar properties to biomass of basil, lettuce and pansy cultivated in growing media. Sci. Hortic. 2020, 261, 109001. [CrossRef]

35. IUSS Working Group WRB. World Reference Base for Soil Resources 2014. In International Soil Classification System for Naming Soils and Creating Legends for Soil Maps; FAO: Rome, Italy, 2014; ISBN 9789251083697.

36. Uchimiya, M.; Wartelle, L.H.; Klasson, K.T.; Fortier, C.A.; Lima, I.M. Influence of Pyrolysis Temperature on Biochar Property and Function as a Heavy Metal Sorbent in Soil. J. Agric. Food Chem. 2011, 59, 2501-2510. [CrossRef]

37. Enders, A.; Hanley, K.; Whitman, T.; Joseph, S.; Lehmann, J. Characterization of biochars to evaluate recalcitrance and agronomic performance. Bioresour. Technol. 2012, 114, 644-653. [CrossRef]

38. Wiedner, K.; Naisse, C.; Rumpel, C.; Pozzi, A.; Wieczorek, P.; Glaser, B. Chemical modification of biomass residues during hydrothermal carbonization-What makes the difference, temperature or feedstock? Org. Geochem. 2013, 54, 91-100. [CrossRef]

39. Cooper, J.; Greenberg, I.; Ludwig, B.; Hippich, L.; Fischer, D.; Glaser, B.; Kaiser, M. Effect of biochar and compost on soil properties and organic matter in aggregate size fractions under field conditions. Agric. Ecosyst. Environ. 2020, 295, 106882. [CrossRef]

40. Wang, L.; O'Connor, D.; Rinklebe, J.; Ok, Y.S.; Tsang, D.C.; Shen, Z.; Hou, D. Biochar Aging: Mechanisms, Physicochemical Changes, Assessment, And Implications for Field Applications. Environ. Sci. Technol. 2020, 54, 14797-14814. [CrossRef]

41. Baldock, J.A.; Smernik, R.J. Chemical composition and bioavailability of thermally altered Pinus resinosa (Red pine) wood. Org. Geochem. 2002, 33, 1093-1109. [CrossRef]

42. Yao, F.; Arbestain, M.C.; Virgel, S.; Blanco, F.; Arostegui, J.; Maciá-Agulló, J.; Macías, F. Simulated geochemical weathering of a mineral ash-rich biochar in a modified Soxhlet reactor. Chemosphere 2010, 80, 724-732. [CrossRef]

43. Aller, M.F. Biochar properties: Transport, fate, and impact. Crit. Rev. Environ. Sci. Technol. 2016, 46, 1183-1296. [CrossRef]

44. Enders, A.; Lehmann, J. Proximate Analyses for Characterising Biochars; Singh, B., CampsArbestain, M., Lehmann, J., Eds.; Csiro Publishing: Melbourne, Australia, 2017; ISBN 978-1-4863-0509-4.

45. Amelung, W.; Brodowski, S.; Sandhage-Hofmann, A.; Bol, R. Combining Biomarker with Stable Isotope Analyses for Asses-sing the Transformation and Turnover of Soil Organic Matter. In Advances in Agronomy; Sparks, D.L., Ed.; Academic Press Inc: Cambridge, MA, USA, 2008; Volume 100, pp. 155-250. ISBN 978-0-12-374361-9.

46. Yousaf, B.; Liu, G.; Wang, R.; Abbas, Q.; Imtiaz, M.; Liu, R. Investigating the biochar effects on C-mineralization and sequestration of carbon in soil compared with conventional amendments using the stable isotope (813C) approach. GCB Bioenergy 2017, 9 , 1085-1099. [CrossRef]

47. Zimmerman, A.R.; Gao, B.; Ahn, M.-Y. Positive and negative carbon mineralization priming effects among a variety of biocharamended soils. Soil Biol. Biochem. 2011, 43, 1169-1179. [CrossRef]

48. Wang, J.; Xiong, Z.; Kuzyakov, Y. Biochar stability in soil: Meta-analysis of decomposition and priming effects. GCB Bioenergy 2016, 8, 512-523. [CrossRef]

49. Setia, R.; Marschner, P.; Baldock, J.; Chittleborough, D.; Smith, P.; Smith, J. Salinity effects on carbon mineralization in soils of varying texture. Soil Biol. Biochem. 2011, 43, 1908-1916. [CrossRef]

50. Wen, Y.; Bernhardt, E.S.; Deng, W.; Liu, W.; Yan, J.; Baruch, E.M.; Bergemann, C.M. Salt effects on carbon mineralization in southeastern coastal wetland soils of the United States. Geoderma 2019, 339, 31-39. [CrossRef]

51. Luo, M.; Huang, J.-F.; Zhu, W.-F.; Tong, C. Impacts of increasing salinity and inundation on rates and pathways of organic carbon mineralization in tidal wetlands: A review. Hydrobiologia 2019, 827, 31-49. [CrossRef]

52. Ventura, M.; Alberti, G.; Viger, M.; Jenkins, J.R.; Girardin, C.; Baronti, S.; Zaldei, A.; Taylor, G.; Rumpel, C.; Miglietta, F.; et al Biochar mineralization and priming effect on SOM decomposition in two European short rotation coppices. GCB Bioenergy 2015, 7, 1150-1160. [CrossRef]

53. Von Glisczynski, F.; Sandhage-Hofmann, A.; Amelung, W.; Pude, R. Biochar-compost substrates do not promote growth and fruit quality of a replanted German apple orchard with fertile Haplic Luvisol soils. Sci. Hortic. 2016, 213, 110-114. [CrossRef]

54. Faucon, M.-P.; Houben, D.; Reynoird, J.-P.; Mercadal-Dulaurent, A.-M.; Armand, R.; Lambers, H. Chapter Two-Advances and Perspectives to Improve the Phosphorus Availability in Cropping Systems for Agroecological Phosphorus Management. In Advances in Agronomy; Sparks, D.L., Ed.; Academic Press: Cambridge, MA, USA, 2015; Volume 134, pp. 51-79.

55. Kumar, S.; Bharti, A. Management of Organic Waste; BoD—Books on Demand: Norderstedt, Germany, 2012; ISBN 978-953-307-925-7.

56. Schulz, H.; Glaser, B. Effects of biochar compared to organic and inorganic fertilizers on soil quality and plant growth in a greenhouse experiment. J. Plant. Nutr. Soil Sci. 2012, 175, 410-422. [CrossRef]

57. Sanchez-Monedero, M.; Cayuela, M.; Roig, A.; Jindo, K.; Mondini, C.; Bolan, N. Role of biochar as an additive in organic waste composting. Bioresour. Technol. 2018, 247, 1155-1164. [CrossRef]

58. Libutti, A.; Rivelli, A.R. Quanti-Qualitative Response of Swiss Chard (Beta Vulgaris L. Var. Cycla) to Soil Amendment with Biochar-Compost Mixtures. Agronomy 2021, 11, 307. [CrossRef]

59. Kammann, C.I.; Schmidt, H.-P.; Messerschmidt, N.; Linsel, S.; Steffens, D.; Müller, C.; Koyro, H.-W.; Conte, P.; Joseph, S. Plant growth improvement mediated by nitrate capture in co-composted biochar. Sci. Rep. 2015, 5, 11080. [CrossRef] [PubMed] 
60. Doan, T.T.; Sisouvanh, P.; Sengkhrua, T.; Sritumboon, S.; Rumpel, C.; Jouquet, P.; Bottinelli, N. Site-specific effects of organic amendments on parameters of tropical agricultural soil and yield: A field experiment in three countries in Southeast Asia. Agronomy 2021, 10. in press.

61. Von Glisczynski, F.; Pude, R.; Amelung, W.; Sandhage-Hofmann, A. Biochar-compost substrates in short-rotation coppice: Effects on soil and trees in a three-year field experiment. J. Plant. Nutr. Soil Sci. 2016, 179, 574-583. [CrossRef] 